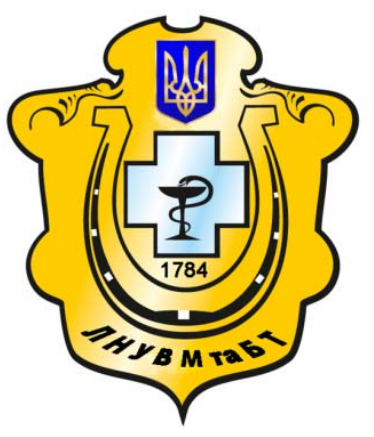

Науковий вісник Львівського національного університету ветеринарної медицини та біотехнологій імені С.3. Гжицького

Scientific Messenger of Lviv National University of Veterinary Medicine and Biotechnologies named after S.Z. Gzhytskyj

doi:10.15421/nvlvet7043

ISSN 2413-5550 print

ISSN 2518-1327 online

$\underline{\text { http://nvlvet.com.ua/ }}$

УДК 639.215.2.043:612.12

\title{
Зміни білкових показників крові коропа за використання комплексу симбіонтних мікроорганізмів
}

\author{
T.В. Мазур, І.Є. Гаркуша \\ florindo.aretuzi@yandex.ru \\ Національній університет біоресурсів и природокористування Украӥни, \\ вул. Потехіна, 16, м. Київ, 03041, Україна
}

\begin{abstract}
За сучасних умов інтенсифікації вирощування та розведення риби нині промислове рибнищтво грунтується на принципах технологічного конвеєра. Одним із шляхів вдосконалення технологій вирощування і розведення риб і підтримки нормального фізіологічного статусу є застосування пробіотичних мікроорганізмів. Культури, щуо входять до їх складу можуть продукувати різні активні речовини, утилізувати шкідливі продукти обміну, надавати антагоністичний вплив на патогенні мікроорганізми. Відомо що застосування пробіотиків впливає на клітинний $i$ біохімічний склад крові, у тому числі $і$ на показники рівня білка у крові. Метою даних досліджень було встановити впливу комплексу пробіотичних мікроорганізмів Bacillus subtillis i Lactobacillus acidophilus в порівнянні з застосуванням монокультур даних мікроорганізмів на білкові фракиії крові коропа звичайного. Завдяки моніторингу рівня вмісту загального білка в сироватчі крові можливе отримання найбільш точних даних про імунний статус коропа. Було виявлено,щя включення в раціон коропів пробіотичного комплексу, щзо складався з Bacillus subtilis ma Lactobacillus acidophilus більш позитивно впливаєа на вміст в крові загального білка та його фракцій в сироватці крові коропів, ніж використання останніх в монокультурах. Окрім того дані вказують на інтенсифікацію обмінних процесів в організмі риб. Разом з тим зростання рівня $\gamma$-глобулінів свідчить про позитивний вплив пробіотиного комплексу на гуморальні фактор імунітету організму коропів.

Ключові слова: загальний білок, глобуліни, короп, симбіонтні мікроорганізми, біохімічний склад крові, про біотичний комплекс, альбуміни, білковий коефіцієнт, сироватка крові.
\end{abstract}

\section{Изменения белковых показателей крови карпа при использовании ком- плекса симбиотичских микроорганизмов}

\author{
Т.В. Мазур, И.Е. Гаркуша \\ florindo.aretuzi@yandex.ru \\ Национальный университет биоресурсов и природопользования Украины, \\ ул. Потехина, 16, г. Киев, 03041, Украина
}

\begin{abstract}
В современных условиях интенсификации выращивания и разведения рыбы сейчас промышленное рыбоводство основывается на принципах технологического конвейера. Одним из путей совершенствования технологий выращивания и разведения рыб и поддержания нормального физиологического статуса является применение пробиотических микроорганизмов. Культуры, входящих в их состав могут производить различные активные вещества, утилизировать вредные продукты обмена, оказывать антагонистическое влияние на патогенные микроорганизмы. Известно, что применение пробиотиков влияет на клеточный и биохимический состав крови, в том числе и на показатели уровня белка в крови. Целью данных исследований было установить влияние комплекса пробиотических микроорганизмов Bacillus subtillis u Lactobacillus acidophilus по сравнению с применением монокультур данных микроорганизмов на белковые фракиии крови карпа обыкновенного. Было обнаружено, что включение в рацион карпов пробиотического комплекса, состоящего из Bacillus subtilis $u$ Lactobacillus acidophilus более положительно влияет и на содержание в крови общего белка и его фракций в сыворотке
\end{abstract}

Citation:

Mazur, T., Garkusha, I. (2016). Changes of protein blood indices of carp using the complex of symbiotic microorganisms. Scientific Messenger LNUVMBT named after S.Z. Gzhytskyj, 18, 3(70), 181-183. 
крови карпов, чем использование последних в монокультурах. Кроме того данные указывают на интенсификацию обменных прочессов в организме рыб.

Ключевые слова: общиий белок, глобулины, карп, симбионтной микроорганизмы, биохимический состав крови, о биотический комплекс, альбумины, белковый коэффициент, сыворотка крови.

\title{
Changes of protein blood indices of carp using the complex of symbiotic microorganisms
}

\author{
T. Mazur, I. Garkusha \\ florindo.aretuzi@yandex.ru \\ National university of life and environmental sciences of Ukraine,
Potekhin Str., 16, Kyiv, 03041, Ukraine
}

\begin{abstract}
In modern conditions the intensification of cultivation and fish farming industrial fish farming today is based on the principles of technological pipeline. One way of improving the technology of cultivation and breeding of fish and maintain normal physiological status is the use of probiotic microorganisms. Fruits included in their composition can produce different active substances disposed of harmful metabolic products provide an antagonistic effect on pathogens. It is known that the use of probiotics affect the cellular and biochemical composition of blood, including the performance level of protein in the blood. The purpose of these studies was to determine the impact of complex probiotic microorganism Bacillus subtillis and Lactobacillus acidophilus compared with the use of these monocultures of microorganisms on the blood protein fractions of common carp. Through monitoring of total protein in serum may receive the most accurate information about the immune status carp. It was found that the inclusion in the diet of carp probiotic complex consisting of Bacillus subtilis and Lactobacillus acidophilus vplyvayea more positive on blood levels of total protein and its fractions in the serum of carp than using the latest in a monoculture. Besides data indicate intensification of metabolic processes in the body of the fish. However, the increase in $\gamma$-globulins shows a positive effect probiotynoho complex on humoral immunity factor
\end{abstract} carp.

Key words: total protein, globulin, carp, symbiontni microorganisms, biochemical composition of blood, the biotic complex, albumin, a protein coefficient, serum.

\section{Вступ}

Сучасне промислове рибництво грунтується на принципах технологічного конвеєра. I одним із шляхів вдосконалення технологій вирощування і розведення риб і підтримки нормального фізіологічного статусу $є$ застосування пробіотичних мікроорганізмів. Культури, що входять до їх складу можуть продукувати різні активні речовини, утилізувати шкідливі продукти обміну, надавати антагоністичний вплив на патогенні мікроорганізми. Так само відомо що застосування пробіотиків впливає на клітинний і біохімічний склад крові. У тому числі і на показники білка в крові (Kamyshnikov, 2004; Bijak et al., 2008).

Велике діагностичне значення має білковий коефіцієнт - відношення кількості альбуміну до кількості глобуліну. Як відомо, значення білкового коефіцієнта у риб істотно нижче, ніж у теплокровних тварин і людини, у яких величина білкового коефіцієнта знаходиться в межах 1,2 - 2,0. Це пояснюється еволюційно-екологічними особливостями білкового складу крові риб (Fasaic et al., 1995).

Таким чином, за білковим складом і співвідношенням білкових фракцій, а також активності амінотрансфераз сироватки крові можна судити про стан організму риб і навколишнього їхнього середовища в той чи інший момент і при необхідності впливати на ці компоненти з метою підвищення антиоксидантної здатності організму риб і, відповідно, якості популяцій (Kondrahin et al., 1985).

Метою досліджень було встановити впливу комплексу пробіотичних мікроорганізмів Bacillus subtillis і Lactobacillus acidophilus в порівнянні з застосуван- ням монокультур даних мікроорганізмів на білкові фракції крові коропа звичайного.

\section{Матеріал і методи досліджень}

Для досліджень досліджували годовиков коропа звичайного. Для досліджень риби були відібрані 3 Тригірського водосховища і ряду приватних водойм. Загальний вміст білків в сироватці крові визначали методом Лоурі та ін. Для дослідження білкових фракцій сироватки крові риб використовували метод i діагностичний набір для електрофоретичного розділення білків сироватки крові на агарозе. Розшифровки фореграмм здійснювали на денсіометрі. Отримані результати обробляли статистично за загальноприйнятою методикою 3 використанням t-критерію Стьюдента (Stroganov, 1964).

\section{Результати та їх обговорення}

Одним 3 найбільш важливих показників, що характеризують вплив пробіотика на стан організму, показник вмісту загальної кількості білка в сироватці крові, а також його фракцій. Завдяки моніторингу рівня вмісту загального білка в сироватці крові можливе отримання найбільш точних даних про імунний статус коропа. В результаті наших досліджень встановлено, що вміст загального білка в сироватці крові на початку досліду був менше, ніж в кінці досліджень. Зміст загального білка у риб контрольної групи в кінці досліду становило 28,5 г/л, в групі де застосовувався комплекс Bacillus subtilis i Lactobacillus acidophilus - 34,2 г / л (підвищення рівня на 21,1\%), в 
дослідній групі де застосовулася монокультура Bacillus subtilis - 32,55 г/л (14,2\%) і результати згодовування монокультури Lactobacillus acidophilus принесли результати в 2,3\%. Показник значення загального білка за застосування комплексу був краще результат використання монокультур на 17\%. Також було встановлено відмінності за змістом білкових фракцій в сироватці в кінці досвіду.
В результаті згодовування пробиотического комплексу спостерігається підвищення загального білка в сироватці (на 21,1\%) і коригування процентної кількості альбумінів і глобулінів. Показник значення загального білка за застосування комплексу був краще результат використання монокультур на $17 \%$.

Таблиия 1

Показники загального білка і деяких його фракцій в процесі експерименту $(\mathrm{M} \pm \mathbf{m}, \mathbf{n}=\mathbf{6})$

\begin{tabular}{|l|c|c|c|}
\hline & Загальний білок, \\
г/л & $\begin{array}{c}\text { Альбуміни, } \\
\text { г/л }\end{array}$ & $\begin{array}{c}\text { Глобуліни, } \\
\text { Г/л }\end{array}$ \\
\hline $\begin{array}{l}\text { Комплекс Bacillus } \\
\text { subtilis та Lactobacillus acidophilus }\end{array}$ & $34,20 \pm 0,5$ & $14,9 \pm 0,22$ & $19,3 \pm 0,27$ \\
\hline Монокультура Bacillus subtilis & $32,55 \pm 0,49$ & $13,5 \pm 0,2$ & $19,05 \pm 0,29$ \\
\hline Монокультура Lactobacillus acidophilus & $29,15 \pm 0,43$ & $14,7 \pm 0,21$ & $14,45 \pm 0,22$ \\
\hline Контроль & $28,5 \pm 0,45$ & $13,1 \pm 0,198$ & $15,4 \pm 0,25$ \\
\hline
\end{tabular}

Зміни кількості альбуміну та фракцій глобулінів, \%

Табличя 2

\begin{tabular}{|l|c|c|c|c|c|}
\hline & Альбумін, \% & $\alpha 1, \%$ & $\alpha 2, \%$ & $\beta, \%$ & $\gamma, \%$ \\
\hline $\begin{array}{l}\text { Комплекс Bacillus } \\
\text { subtilis та Lactobacillus acidophilus }\end{array}$ & $38,24 \pm 2,14$ & $9,52 \pm 0,77$ & $12,65 \pm 0,96$ & $29,34 \pm 2,30$ & $10,25 \pm 0,81$ \\
\hline Монокультура Bacillus subtilis & 39,25 & 9,75 & 13,15 & 29,25 & 8,6 \\
\hline Монокультура Lactobacillus acidophilus & 40,9 & 10,0 & 14,9 & 29,0 & 5,2 \\
\hline Контроль & 41,2 & 10,1 & 15,4 & 28,8 & 4,5 \\
\hline
\end{tabular}

Вміст $\alpha 1-$ глобулінів в сироватці крові у коропів першої дослідної групи після дачі пробіотика зменшився $з 10,1 \pm 0,8$ до 9,52 $\pm 0,77 \%$, рівень $\alpha 2-$ глобулінів виріс - $315 \pm 1,7$ до 12,65 $\pm 0,96 \%$, концентрація $\beta$-глобуліну - $з$ 28,8 $\pm 1,91$ до 29,34 $\pm 2,30 \%$. Після згодовування комплексу пробіотичних мікроорганізмів першої дослідної групи риб спостерігалося підвищення вмісту $\gamma$-глобуліну сироватки крові 3 $16,79 \pm 2,81$ до $10,25 \pm 0,81 \%$. У сироватці крові риб яким згодовувався комплекс Bacillus subtilis i Lactobacillus acidophilus спостерігалося зменшення концентрації альбуміну з 41,2 до $38,24 \%$, що свідчить про позитивну роботу печінки і дає більш значиму інформацію, ніж просто загальний білок.

\section{Висновки}

Отже включення в раціон коропів пробіотичного комплексу, що складався з Bacillus subtilis та Lactobacillus acidophilus більш позитивно вплинула на вміст в крові загального білка та його фракцій в сироватці крові коропів, ніж використання останніх в монокультурах. Окрім того отримані дані вказують наінтенсифікацію обмінних процесів в організмі риб. А зростання рівня $\gamma$-глобулінів свідчить про позитивний вплив пробіотиного комплексу на гуморальні фактор імунітету організму коропів.

\section{Бібліографічні посилання}

Bijak V.Ja., Synjuk, Ju.V., Kurant, V.Z. (2008). Vydovi osoblyvosti frakcijnogo skladu bilkiv syrovatky krovi prisnovodnyh ryb. Dop. Nac. akad. nauk Ukrai'ny, Ternopil'. nac. ped un-t im. V. Gnatjuka. 4, 189-192 (in Ukrainian).

Kamyshnikov, V.V. (2004). Spravochnik po klinikobiohimicheskim issledovanijam i laboratornoj diagnostike. M.:MEDPress-inform. 56-60 (in Russian).

Kondrahin, I.P., Kurilov, N.V., Malahov, A.G. i dr. (1985). Klinicheskaja laboratornaja diagnostika v veterinarii: spravochnoe izdanie. M.: Agropromizdat (in Russian).

Stroganov, N.S. (1962). Jekologicheskaja fiziologija ryb. M.: Izd-vo Mosk. un-ta. 1, 144 (in Russian).

Fasaic, K., Debeljak, Lj., Adamek, Z. (1995). Neki hematoloski pokzateli u uzgoju dvogodisnjeg sarana (Cyprinus carpio L.) [Some haematological indicators by the cultivation of a two-year carp (Cyprinus carpio L.)]. Ribarstvo. 53, 3, 95-103 (in Russian).

Стаття надійшла до редакиії 6.09.2016 